\title{
Effect of Consumer Confidence Index, Interest Rate, Stock Market Composite Index, and Inflation on the Net Asset Value of Indonesian Mutual Funds
}

\author{
Handy Nugraha* Lukman Hakim Dwi Prasetyani \\ Economics and Development Studies,Faculty of Economics \&Business, \\ Universitas Sebelas Maret,Indonesia
}

\begin{abstract}
The growth of the mutual fund industry will continue to grow positively in line with the condition of the national economy, which is starting to recover from the crisis caused by the pandemic. It is essential to study the factors that influence this phenomenal growth to carry out risk mitigation. This research focuses on the factors that affect the NAV fluctuation by considering macroeconomic dimensions such as the consumer confidence index, interest rates, the stock market composite indexes, and inflation as independent variables. The study uses monthly time series data with the period from January 2013 to December 2020. The VAR model performed in the study proved that only the Composite Stock Price Index variable in the previous month significantly affects the Net Asset Value prices in the short- term. The impulse response function also confirms a strong relationship. The Composite Stock Price Index can influence the fluctuations to the Net Asset Value of Indonesia mutual funds. The composite stock price index can be used as a particular consideration when assessing the Indonesian mutual funds.
\end{abstract}

Keywords: Mutual Funds; Consumer Confidence Index; Interest rate; stock market composite indexes, mutual funds

DOI: $10.7176 / \mathrm{EJBM} / 13-21-01$

Publication date: November $30^{\text {th }} 2021$

\section{Introduction}

Increasing investment is crucial in accelerating economic development (Susic et al., 2017). Mutual funds are one of the investment instruments in the Indonesian capital market that are in great demand by the public with high growth in the last eight years(Robiyanto et al., 2019; Gusni et al., 2018). In 2013-2020, the growth of the Indonesian mutual fund industry consistently reached a high record, which was reflected in the aggregated Net Asset Value (NAV)(Indrakusuma, 2018). In 2020, the NAV of the Indonesian mutual fund industry reached IDR 573.54 trillion; this value is the highest record in history(Table 1). However, this fact is not in line with national economic conditions because it coincides with Indonesia's economic recession due to the Covid-19 pandemic. The Indonesian economy officially experienced a recession in the third quarter; after the second quarter, economic growth also contracted or was negative, while the NAV continued to grow. Table 1 shows the situation case of the mutual fund industry NAV and economic growth in Indonesia.

Table 1:Net Asset Value and Economic Growth 2020

\begin{tabular}{lcc}
\hline \multicolumn{1}{c}{ Month } & Net Asset Value (Rp Trillion) & Economic Growth (Percent) \\
\hline March & 471,87 & 2,97 \\
\hline June & 482,55 & $-5,32$ \\
\hline September & 510,15 & $-3,49$ \\
\hline December & 573,54 & $-2,19$ \\
\hline
\end{tabular}

Source: Financial Services Authority and Central Statistics Agency (processed)

The Covid-19 pandemic has shaken the global and national economy, but what is interesting is that the Indonesian mutual fund industry continues to grow. The COVID-19 outbreak has delivered an unprecedented negative shock to the global economy and plunged financial markets into turmoil, but early indications suggest that investment activity is resisting remarkably well(Burger et al., 2017). Research on the NAV of mutual funds is essential because the NAV of a mutual fund is a picture of the investors' gains/losses on their chosen mutual fund investment. If the NAV/unit is higher than the NAV/unit value at the time of purchase, the investor is said to have made a profit after the redemption has occurred. If the NAV/unit is lower at the time of purchase, investors should hold their funds to avoid losses. When prices fall, investors should subscribe so that the number of units increases. $\mathrm{NAV}$ /unit is also an illustration of the market timing ability of a mutual fund investment manager, where stock market volatility does not occur twice(Ratnaraju \& Madhav, 2016).

Similar researches better defend the macroeconomic facts observed in reality. Moreover, Bandono et al.(2020) state that interest rates positively affect mutual funds. The study of Eldomiaty et al.(2020), which asses the nexus of inflation rates, stock prices, and interest rates, concludes a persistent negative association between stock prices and inflation rates. Goh et al.'s (2021) study shows a significant positive effect of the interest rate on the stock 
market index. However, Bandono et al. (2020) demonstrate that the Indonesian exchange composite index and exchange rate do not significantly influence the NAV/mutual fund. Besides, the study of Harrington \& Saloner (2008)that assesses the relationship between macroeconomic factors and mutual fund prices in Ghana found that interest rate has no significant effect on the NAV/mutual fund both in the short and long run.

The results of Setyani \& Gunarsih's (2018)study show that the composite stock index has a significant effect on the net asset value of Islamic mutual funds, while inflation has a positive influence. The result is consistent with Cheng \& Dewi's (2020) study, which shows that inflation significantly affects the Net Value Aset per unit; when inflation rises, the NAV also rises.

Ashok Panigrahi, Pradhum Karwa (2020) examine the impact of macroeconomic variables on the selected mutual funds in India; the influence is about $52 \%$ on the mutual fund performance. Moreover, Purwaningsih et al. (2017)demonstrate that all selected macroeconomics variables such as inflation, interest rate, and the Indonesian Composite Index positively correlate to the NAV/mutual fund.

Findings from previous studies on interest rates and stock market composite index on mutual funds show contradictory results. Nevertheless, the decision to invest depends on economic conditions. This study aims to confirm the effect of interest rates and stock market composite indexes on the mutual fund industry in the short and long term. This study expands the literature by adding another macroeconomic dimension, namely the consumer confidence index in the Indonesian mutual fund industry, which may not have been studied before.

\subsection{Elucidation of study tools}

\subsubsection{Mutual Fund/Net asset Value}

Guided by the Capital Market Law No. 8 of 1995, Article 1 paragraph (27) defines that Mutual Funds are containers used to collect funds from the investor community to be further invested in securities portfolios by investment managers. The securities portfolio in question is securities in stocks, bonds, and money market instruments. Investors will benefit if the NAV/UP value increases compared to the NAV/UP value at the time of purchase.

\subsubsection{Consumer Confidence Index}

Based on the explanation of Bank Indonesia's Metadata, the Consumer Confidence Index is a simple average of the Current Economic Condition Index and the Consumer Expectations Index. The Current Economic Condition Index includes consumer confidence in current income, timeliness of purchasing durable goods, and job availability by comparing current conditions six months ago. Meanwhile, the Consumer Expectation Index includes consumer confidence regarding consumer expectations of economic conditions in the next six months compared to the current one, including income expectations, general Indonesian economic (business world) conditions, and job availability.

\subsubsection{Interest rate(Bank Indonesia rate)}

According to the Bank Indonesia, the BI. Rate is the reference interest rate determined by the Bank Indonesia through the Board of Governors' Meeting every month. Once determined, the BI. Rate is forwarded to the public as a reference for credit and savings reference rates. Considering other economic factors, Bank Indonesia will generally increase the BI rate if future inflation is predicted to exceed the set target. On the other hand, Bank Indonesia will lower the BI rate if future inflation is below the set target. In this study, the BI rate is used to determine the effect of government policy on banking interest rates on the impact of mutual fund investment.

1.1.4. Composite Stock Price Index (CSPI)

The Composite Stock Price Index is a composite of the stock prices of listed companies that trade on the Indonesia Stock Exchange (IDX). The composite stock price index is used to measure the combined performance of all stocks listed on the stock exchange. The composite stock price index is formed from the number of share prices multiplied by the weight of the shares divided by the basic value, namely the value formed based on the number of shares listed on the IDX (Indonesian Stock Exchange), which are included in the index calculation. So, the initial hypothesis that can be raised here is that the CSPI will affect the NAV of mutual funds because the placement of mutual fund portfolios, especially equity funds, is in the stock sector.

\section{Research methods}

2.1.Econometric design

The analysis is based on VAR / VECM modelling, which in econometrics dates back to Sims (1980), who wanted an alternative to seeing an improvement to simultaneous equation models. Without resorting to an upstream economic theory, this modelling allows us to have a relatively well-adapted framework for our study. It will make it possible to analyze the impact of fluctuations on the Indonesian Mutual Fund Industry in the short- and longterm magnitude.

Statistically, a VAR model involves variables treated symmetrically without any exclusion condition and with the same length of delay for each.

The simplest form is that of the unconstrained VAR model (Unrestricted Vector Auto-regressive: UVAR), whose writing is: 


$$
\begin{aligned}
& Y_{1 t}=\emptyset_{1 l}^{(1)} Y_{1, t-1}+\cdots+\emptyset_{1 l}^{(p)} Y_{1, t-p}+\cdots+\emptyset_{1 n}^{(1)} Y_{n, t-1}+\cdots+\emptyset_{1 n}^{(p)} Y_{n, t-p}+\varepsilon_{1 t} \\
& Y_{n t}=\emptyset_{n l}^{(1)} Y_{1, t-1}+\cdots+\emptyset_{n l}^{(p)} Y_{1, t-p}+\cdots+\emptyset_{n n}^{(1)} Y_{n, t-1}+\cdots+\emptyset_{n n}^{(p)} Y_{n, t-p}+\varepsilon_{n t}
\end{aligned}
$$

where,

n: number of model variables,

p: number of delays,

$\emptyset_{1 j}$ : coefficients of the variables of the model of the polynomial matrix F ( $\mathrm{p}$ ) in the delay operator,

$\varepsilon_{t}: \quad$ White noise process.

Monfort [1990, p. 3] gave more synthetic writing in the reduced form :

$Y_{t}=\Phi^{*}(L) Y_{t}+\varepsilon_{t}$

where $\Phi^{*}(L)$ is the size (n, n) matrix of the coefficients $\Phi_{i j}$ such that $\Phi(L)=\Phi^{*}(L)-L$ in autoregressive writing, with $\Phi(L)(\mathrm{L}) \mathrm{Yt}=\varepsilon_{t}$, where $\Phi(L)$ is a matrix of size $(\mathrm{n}, \mathrm{n})$ of $\mathrm{L}$-lag polynomials of degree $\mathrm{p}$.

An essential property of the time series is its stationarity. If a process is stationary, this means that its statistical properties do not vary over time, namely its mean, its variance (homoscedasticity) or its covariance.

\subsection{Data source}

The type of data used in this study is secondary data in time series from January 2013 to December 2020. The independent variables include the Consumer Confidence Index(CCI), Interest Rates(IR), Composite Stock Price Index(CSPI), and Inflation(INFL). At the same time, the dependent variable is the Net Asset Value (NAV) of the Indonesian Mutual Fund Industry. Data are from the Financial Services Authority (OJK), Bank Indonesia (BI), and the Indonesia Stock Exchange (IDX).

\section{Empirical results and discussion.}

\subsection{Unit root test}

The unit root test, for example, that of Dickey-Fuller, consists in testing the hypothesis, against the alternative hypothesis, in the following equation:

$$
X_{t}=\rho x_{t-1}+u_{t}
$$

Where, $u_{t}$ is a white noise error. If $\rho=1$ then the variable $X_{t}$ is an integrated variable of order 1 .

This is the case with the driftless random walk model. If $\rho<1$ then the variable $X_{t}$ is stationary.

If $\rho=1$, the variance of $X_{t}$ is dependent on $t$, which goes against the condition of stationarity; on the other hand, if $\rho<1$, the variance of $X_{t}$ is independent of $t$ (constant).

\begin{tabular}{|c|c|c|c|c|}
\hline Variables & At level & At first Difference & Conclusion & \\
\hline NAV & & -2.066841 & $-4900723 * * *$ & I (1) \\
\hline CCI & & -1.845467 & $-8.669595 * * *$ & I (1) \\
\hline IR & & -2.218798 & $-4.435343 * * *$ & I (1) \\
\hline CSPI & & -2.588377 & $-7.684656 * * *$ & I (1) \\
\hline INFL & & -4.066081 & $-7.618056 * * *$ & I (1) \\
\hline
\end{tabular}

The statistic for this test is the usual $t$ statistic with critical values calculated by Dickey and Fuller.

Table2: ADF test result

*indicates a significant level at 5\%

Table 2 shows that of the five variables, Net Asset Value (NAV), Consumer Confidence Index (CCI), Interest Rate (IR), Composite Stock Price Index (CSPI), and Inflation (INFL) are not stationary z $(\mathrm{t})>0.05$. The sequential Augmented Dicky Fuller test (ADF) shows that the difference series are stationary $(* * *)$ and are integrated of order 1 .

\subsection{Optimum Lag Test}

We used the AKAIKE (AIC) and SCHWARZ (SC) criteria to determine the number of delays. In the case of VAR representation, these criteria are crucial to determine the order $p$ of the model ( $p$ is the optimal number of delays). Thus, and from the table below, we can determine the optimal lag of our model. 
Table 3: Optimum Lag Test Results

\begin{tabular}{llll}
\hline Lag & & AIC & SC \\
\hline 0 & 94.85901 & 94.99606 & \\
\hline 1 & $\mathbf{8 2 . 8 6 0 2 6}^{*}$ & $83.68258^{*}$ & \\
\hline 2 & 82.92345 & 84.43105 \\
\hline 3 & 83.14089 & 85.33375 \\
\hline 4 & 83.25078 & 86.12891 \\
\hline
\end{tabular}

*indicates lag order selected by the criterio

\subsection{Johansen cointegration tests}

We performed the cointegration test based on the comparison of the likelihood ratio to its critical value.

For a given significance threshold, the null hypothesis situating a cointegration relation between the model variables is accepted if the trace (TR) value is less than its tabulated critical value. On the other hand, a value of the trace greater than its critical value implies that there is no cointegration between variables.

Table 5: Johansen Cointegration Test Results

\begin{tabular}{lcccc}
\hline $\begin{array}{l}\text { Hypothesized } \\
\text { No. Of CE (s) }\end{array}$ & Eigenvalue & Trace Statistic & $\begin{array}{c}0.05 \\
\text { Critical Value }\end{array}$ & Prob.** \\
\hline None & 0.286098 & 65.71904 & 69.81889 & 0.1017 \\
\hline At most 1 & 0.190411 & 34.37708 & 47.85613 & 0.4813 \\
\hline At most 2 & 0.079182 & 14.73283 & 29.79707 & 0.7971 \\
\hline At most 3 & 0.062312 & 7.061001 & 15.49471 & 0.5707 \\
\hline At most 4 & 0.011520 & 1.077600 & 3.841465 & 0.2992 \\
\hline
\end{tabular}

The trace results were obtained assuming the presence of a constant and the absence of a deterministic trend in the long-term relationship. With the null hypothesis of the absence of cointegration, the value of all trace statistics is lower than the critical value. We retain the null hypothesis of the absence of cointegration among variables. The same is true for the other hypotheses.

Therefore, building a VAR model seems opportune, and verifying the short-run links between dependant and independent variables and their meaning seems opportune.

\subsection{VAR estimations}

For a stationary VAR model, the stationarity of the series will lead to the convergence and the asymptotic normality of the estimators obtained by the ordinary least squares method, which makes it possible to carry out tests on the model's parameters. There are five specifications from the VAR model specification, but as part of our analysis, we will dwell more on the NAV equation and analyze the impacts of CCI, IR, CSPI, and INFL on the NAV.

Table 6: VAR model estimation results

\begin{tabular}{|c|c|c|}
\hline Variables & Coefficients & P-value \\
\hline NAV(-1) & 0.846253 & 0.0000 \\
\hline NAV $(-2)$ & 0.111282 & 0.4706 \\
\hline CCI(-1) & $-1.37 \mathrm{E}+11$ & 0.6065 \\
\hline CCI(-2) & $-2.78 \mathrm{E}+11$ & 0.2648 \\
\hline CSPI(-1) & $1.76 \mathrm{E}+10$ & 0.0286 \\
\hline CSPI(-2) & $-9.14 \mathrm{E}+09$ & 0.2112 \\
\hline INFL(-1) & $-2.83 E+11$ & 0.8885 \\
\hline INFL(-2) & $7.66 \mathrm{E}+10$ & 0.9689 \\
\hline IR(-1) & $-3.15 E+12$ & 0.5847 \\
\hline IR(-2) & $1.62 \mathrm{E}+12$ & 0.7710 \\
\hline $\mathrm{C}$ & $3.19 \mathrm{E}+13$ & 0.0330 \\
\hline R-squared & 0.994284 & \\
\hline Adjusted R-squared & 0.993595 & \\
\hline
\end{tabular}

Table 7: VAR Model Stability Test

\begin{tabular}{ll}
\hline Root & Modulus \\
\hline 0.409530 & 0.409530 \\
\hline 0.240231 & 0.240231 \\
\hline-0.165813 & 0.165813 \\
\hline-0.064296 & 0.064296 \\
\hline
\end{tabular}

The short-term balanced relationship between the independent and dependent variables is carried out according to equation (1). On that basis, this study uses the closing CSPI value of the previous month, which is taken daily at the end of the month (t-1). In general, investments are made for a minimum of one month and are often based on the month's closing price to record the end of the month report. So the use of time lag is very relevant and has proven to get significant results.

From the regression above Table 6, we conclude that the CSPI variable in the previous month had a significant effect on NAV prices in the short- term. The CSPI of one month previously had a significant effect in the short 
term with the coefficient of CSPI(-1) $1.76 \mathrm{E}+10$. The ICSPI price one month earlier had a positive effect on the formation of NAV prices, where every increase in CSPI of Rp. 1 is estimated to cause an increase in NAV of 0.770129 with the same assumptions.

From Table 7, all modulus values $<1$, then the VAR model is stable. Now we can step on the dynamic analyzes.

\subsection{Impulse response function}

Usually, the VAR process is used in practice to determine impulse reactions. Indeed, the function of the impulse responses represents the effect of a shock of innovation on the current and future values of the system's variables. A shock on a variable can directly affect this variable, at the same time as it propagates to all the other variables through the dynamic structure of the VAR. We are interested in the effects of the shock over ten periods (i.e., ten years). This horizon represents the time required for the variables to return to their long-term levels.

Response to Cholesky One SD (d.f. adjusted) Innovation
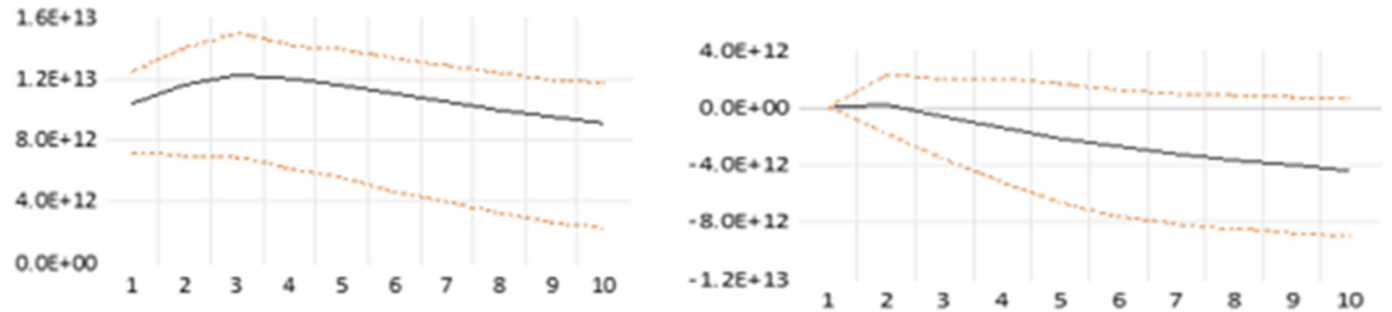

Gravh 1: Resoonse of NAV to NAV
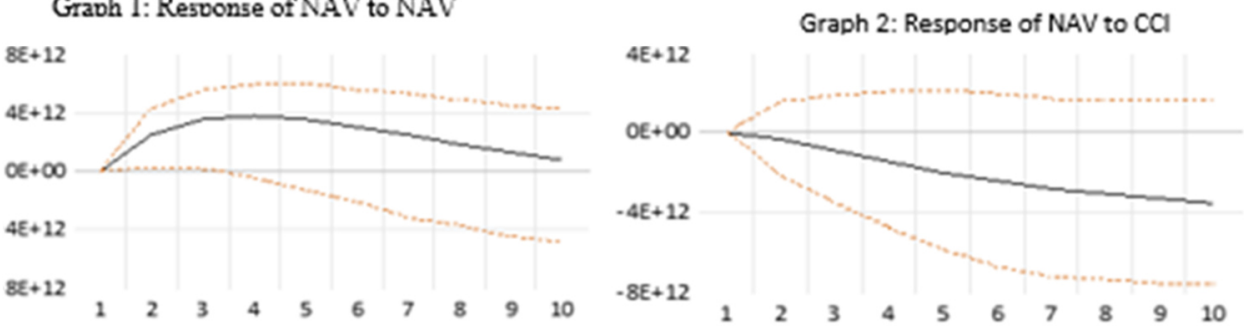

Graph 3: Response of NAV to CSPI

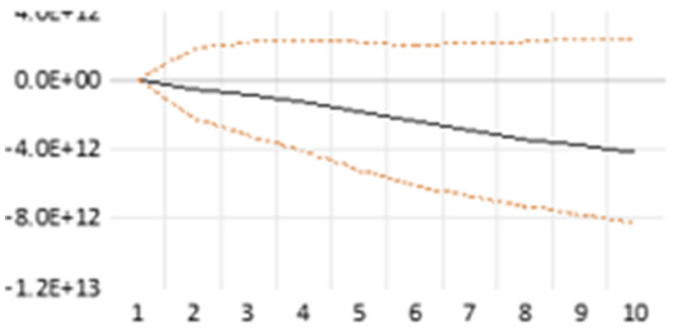

Graph 4: Response of NAV to INFL

Graph 5: Response of NAV to IR innovation.

Within ten years, the growth of NAV varies positively during the first year until the third year, and then it decreases in the following years. We find that the reaction of the composite stock price index to the Net Asset value is crucial(Graph 3). A one standard deviation shock to CSPI causes significant increases in NAV for four periods, after which the effect dissipates. When the CSPI rises, the capital market improves, and the stock market progresses. This market situation shows healthy economic, social and political conditions so that the returns for investors are increasing and vice versa.

However, a positive shock in the Consumer Confidence Index, Interest Rates, Composite Stock Price Index, and Inflation has a negative effect on the Net Asset Value of the Indonesian Mutual Fund Industry.

\section{Conclusion and implication}

The objective pursued in this work consists in studying the empirical influence that exists from the Consumer Confidence Index, Interest Rates, Composite Stock Price Index, and Inflation to the Net Asset Value of the Indonesian Mutual Fund Industry.

The results reveal a short-run relationship between the Composite Stock Price Index and the Net Asset Value of the Indonesian Mutual Fund Industry. This confirms the results given from the impulse response function, according to which the Composite Stock Price Index has a strong relationship and is in line with the NAV of mutual funds. If the Composite Stock Price Index rises/decreases, the NAV of mutual funds will increase/decrease, 
as shown in graph 3. This can be addressed by investors to carefully follow the development of the CSPI price, which is published daily without waiting for reports that are usually sent by the custodian bank as confirmation of account transactions every month. So that investors can easily predict the NAV price so that decisions to place funds or withdraw funds can be made immediately by observing the development of the CSPI. Investors could predict the movement of mutual fund NAV to anticipate the future prevision.

\section{References}

Ashok Panigrahi, Pradhum Karwa, P. J. (2020). Impact of Macroeconomic Variables on the Performance of Mutual Funds: A Selective Study. Journal of Economic Policy \& Research, 15(ISSN 0975-8577), $29-43$.

Bandono, B., Tumbelaka, I., \& Nuryartono, N. (2020). The impacts of general mutual funds and macroeconomic factors on the performance of an infrastructure oriented mutual fund in Indonesia (pp. 1-10).

Burger, A., Damijan, J. P., Kostevc, Č., \& Rojec, M. (2017). Determinants of firm performance and growth during economic recession: The case of Central and Eastern European countries. Economic Systems, 41(4), 569-590. https://doi.org/10.1016/j.ecosys.2017.05.003

Cheng, L., \& Dewi, K. (2020). the Effects of Inflation, Risk, and Money Supply on Mutual Funds Performance. Journal of Applied Finance \& Accounting, 7(1), 29-34. https://doi.org/10.21512/jafa.v7i2.6378

Gusni, Silviana, \& Hamdani, F. (2018). Factors affecting equity mutual fund performance: Evidence from Indonesia. Investment Management and Financial Innovations, 15(1), 1-9. https://doi.org/10.21511/imfi.15(1).2018.01

Harrington, S., \& Saloner, G. (2008). Ashesi University. April, 1-3.

Indrakusuma, H. (2018). The Indonesian Mutual Fund Industry : Challenges and Opportunities. 9-14.

Purwaningsih, S. S., Suryani, A., \& Sartika, E. (2017). The Effect of Inflation, Interest Rate, and Indonesia Composite Index (ICI) to the Performances of Mutual Fund Return and Unit Link with Panel Data Regression Modelling. UNEJ E-Proceeding, Ici, 299-302.

Ratnaraju, P., \& Madhav, V. V. (2016). A study on performance evaluation of mutual funds schemes in India. International Journal of Applied Business and Economic Research, 14(6), 4283-4291.

Robiyanto, R., Santoso, M. A., \& Ernayani, R. (2019). Sharia mutual funds performance in Indonesia. Business: Theory and Practice, 20, 11-18. https://doi.org/10.3846/btp.2019.02

Setyani, D., \& Gunarsih, T. (2018). the Effect of Exchange Rates, Inflation, Jci and the Number of Islamic Mutual Funds on the Net Asset Value of Islamic Mutual. Journal of Applied Economics in Developing Countries, 3(1), 41-51. https://jurnal.uns.ac.id/jaedc/article/view/40116

Susic, I., Stojanovic-Trivanovic, M., \& Susic, M. (2017). Foreign direct investments and their impact on the economic development of Bosnia and Herzegovina. IOP Conference Series: Materials Science and Engineering, 200(1). https://doi.org/10.1088/1757-899X/200/1/012019. 